\title{
Potensi Wisata Kabupaten Indramayu
}

\author{
Wahyu Iryana \\ UIN Raden Intan Lampung, Indonesia \\ Email:wahyu_iryana@yahoo.com
}

\begin{abstract}
Indramayu is an area that has a very rich tourism potential, this is the basic capital of tourism in Indramayu long term. But the main point at issue is how the potential is prospective and actual. Prospective step and actualization is of course a management problem. Therefore, tourism management is an absolute requirement for the development of tourism activities. One concrete form of tourism management is promotion or advertising. Professionalism in doing real work is part of the struggle.
\end{abstract}

Keywords: Indramayu; Potential; Tourism.

\begin{abstract}
Abstrak
Indramayu termasuk daerah yang memiliki potensi wisata yang sangat kaya, ini adalah modal dasar pariwisata di Indramayu jangka panjang. Namun pokok inti yang menjadi permasalahan adalah bagaimana potensi itu prospektif dan aktual. Langkah prospektif dan aktualisasi itu tentu saja adalah problem manajemen. Oleh Karena itu, manajemen kepariwisata menjadi syarat mutlak berkembangnya aktivitas kepariwisataan. Salah satu wujud konkret manajemen pariwisata adalah promosi atau iklan. Profesionalisme dalam melakukan kerja-kerja nyata adalah bagian perjuangan.
\end{abstract}

Kata Kunci: Indramayu; Potensi; Wisata.

\section{A. PENDAHULUAN}

Kabupaten Indramayu merupakan kabupaten di bagian timur laut Provinsi Jawa Barat atau di sekitar Pantai Utara. Letak ibu kota Kabupaten Indramayu sangat dekat dengan muara Sungai Cimanuk (Ensiklopedi Nasional Indonesia, 1989: 138-140). Wilayah darat Indramayu cukup luas mencapai sekitar 209.942 $\mathrm{Ha}$ atau 2.099,42 $\mathrm{km}^{2}$ (BPS, 2014: 3-39). Indramayu juga sering disebut sebagai salah satu wilayah di Pesisir Utara Jawa atau Pantai Utara Jawa (Pantura) ${ }^{1}$. Beberapa penduduk di pesisir laut utara terutama yang berdiam di sekitar pesisir pantai memiliki mata pencaharian sebagai nelayan dan sebagain lagi tentu adalah petani (Iryana, Wahyu, 2019:90).

Perkembangan pemahaman Pariwisata sangat terkait dengan tingkat pendidikan masyarakatnya sebagai referensi potensi sumber daya manusia untuk mewujudkan harapan yang ideal tetang progresifitas wisata di Indramayu. Penopang wisata daerah adalah perkembangan desa wisata sebagai penyangga akan menentukan apresiasi warga terhadap nilai-nilai sosiokultural tertentu dalam usaha menumbuhkan ekonomi yang lebih baik. Dialektika antara perkembangan desa, baik dalam memberikan makna sosial desa, distribusi sosial, segregasi etnis, pengelolaan berbagai sumber material dan berbagai perlembagaan atau pengorganisasian masyarakatanya ditentukan pula oleh tingkat pendidikan itu sendiri (Waliki, 2004).

Kebudayaan daerah Indramayu dan pariwisata harus dikembangkan sedemikian rupa sebagai upaya pengembangan daya saing daerah yang merupakan siklus peristiwa sosial ekonomi yang selalu 
berulang setiap saat. Di samping itu persoalan kebudayaan dan pariwisata merupakan isu kewilayahan yang mengakar karena faktor-faktor yang kompleks. Masalah pengembangan pariwisata daerah Indramayu merupakan masalah yang bersifat multi dimensi sehingga untuk menyelesaikannya diperlukan sebuah solusi menyeluruh. Untuk itu, terlebih dahulu harus diketahui akar masalah yang menjadi penyebab dan menganalisis bagaimana upaya akselerasi meningkatkan pariwisata Indramayu. Tulisan ini merupakan kajian studi pustaka dari beberapa sumber baik dari buku- buku, internet, maupun hasil penelitian penulis.

\section{B. METODE PENELITIAN}

Penelitian terkait Potensi Wisata di Kabupaten Indramayu menggunakan metode penelitian sejarah. Sedangkan untuk teori penulis gunakan teori kausalitas yakni teori yang berbicara tentang sebab akibat terjadinya peristiwa sejarah, baik sebab langsung maupun tidak langsung. Dalam kausalitas, sejarawan menganalisis dua hal pokok, yaitu tentang problem dan solusi. Keduanya berbeda dalam akibat yang ditimbulkan, karena kasus lebih bersifat prosesual tanpa perubahan, sedangkan dalam perubahan terjadi perubahan kausalitas berupa perubahan struktural (struktural change) dan perubahan sistem (systemic chenge) (Gottsalk, 1995; Kuntowijoyo, 2008: 36-37).

\section{Hasil dan Pembahasan}

Potensi adalah kemampuan untuk meningkatkan kualitas dalam hal ini terkait pariwisata di Indramayu. Upaya meningkatkan potensi pariwisata tentu saja merupakan aktivitas yang akan berdampak pada aspek ekonomi, sosial, budaya dan politik. Unsur pentik dalam kegiatan pariwisata umumnya akan melibatkan tiga pihak pilar utama, pertama pihak yang berada dilokasi pariwisata, kedua adalah pihak yang mendatangi tempat wisata sebut saja wisatawan atau para pendatang dan pihak ketiga adalah pihak yang terlbat dalam organisasi penyelenggaraan kepariwisataan dalam hal ini Dinas pariwisata sebagai kepanjangtanganan pihak pemerintah daerah. Ketiag pihak yang disebut di atas pasti akan mendapat pengaruh dari ritual pariwisata secara umum. Tentu saja pengaruh tersebut tidak melulu dimaknai sebagai pengaruh yang positif, tetapi juga pasti ada pengaruh negatif. Walaupun secara keseluruhan pada umumnya semua pihak menginginkan pengaruh positif daripada pengaruh negatif. Indramayu sebagai daerah pesisir tentu saja punya semua potensi tentang pariwisata, untuk mengaktualkan pembangunan ekonomi dengan suatu pertumbuhan yang berimbang kepariwisataan dapat memegang peranan yang menentukan dan dapat dijadikan sebagai katalisator untuk mengembangkan pembangunan sektor-sektor di bidang lain secara bertahap. Pertumbuhan yang berimbang bagi perekonomian itu dapat terjadi sebagai akibat progresnya pertumbuhan insdustri pariwisata yang diorganisir dengan baik.

Apabila perwujudan dan menejemen pariwisata tertata dan terpola dengan baik tentu saja bukan hanya hotel-hotel yang dapat menyediakan kamar-kamar para wisatawan untuk menginap lebih dari itu makanan oleh-oleh khas daerah, perencanaan perjalanan agen wisata yang profesional, industri kerajinan dari desa-desa kreatif di wilayah Indramayu, pramuwisata, tenaga terampik terdidik, pagelaran budaya khas Indramayu. Hal ini pasti akan beriringan dengan penguatan sarana prasarana ekonomi seperti jalan raya, jembatan, terminal, pelabuhan, lapangan udara. Termasuk prasarana lain seperti pembangkit listrik, air bersih, fasilitas olah raga, dan rekreasi, ps, telekomunikasi, jaringan internet, bank, money changer, outlet pakaian, asuransi, periklanan, media, percetakan, dan sektor perekonomian lainnya (Spillane, 1987:46-47).

Konsep pariwisata yang matang harus ditopang dengan kemandirian masyarakat akan pentingnya menjaga stabilitas keamanan, toleransi dan kerja keras. Sisi lain Pariwisata sebagai industri jasa yang digolongkan sebagai industri ketiga berperan penting dalam membuak kesempatan kerja 
masyarakat. Alasan yang paling sederhana adalah semakin mendesaknya tuntutan akan kesempatan kerja yang tetap sehubungan dengan selalu meningkatnya wisata pada masa yang akan datang.

Hubungan-hubungan yang terjalin antara wisatawan dengan masyarat yang dikunjunginya akan menempa nilai hidup baru dalam arti memperluas cakrawala pemandangan pribadi terhadap bilai-nilai kehidupan lainnya secara alami. Masyarakat Indramayu dituntun dewasa menyikapi keadaan dan perkembangan jaman, belajar menghargai nilai-nilai orang lain di samping nilai-nilai yang dimilikinya. Dalam hubungan dengan kegiatan kewisataan dalam negeri, orang akan lebih mengenal tanah kelahiranya. Hal ini akan menumbuhkan sikap toleransi dalam pergaulan yang merupakan saran kuat dalam pembangunan bangsa. Apabila dikaitkan dengan huubungan-hubungan akan hadirnya wisatawan asing, tentu saja hal ini di samping memperluas nilai-nilai pergaulan juga akan memperkuat nilai-nilai pribadi sendiri karena justr nilai pribadi asli yang ramah merupakan daya tarik yang dihargai orang asing tersebut. Para wisatawan ingin sesuatu yang lain dengan yang ada di negaraya; mereka ingin sesuatu yang asli (Spillane, 1987:52).

Pada dasarnya peranan pariwisata dalam pembangunan negara berintikan tiga aspek, yaitu ekonomi (Sumber devisa, pajak-pajak), sosial (penciptaan lapangan kerja), kebudayaan (memperkenalkan udaya tempat wisata Indramayu kepada wisatawan). Perkembangan pariwisata bisa menimbulkan dampak postitif untuk keudayaan pabila bisa merangsang perhatian lebih besar terhadap nilai-nilai budaya yang menjadi khasanah kearifan lokal masyarakat Indramayu, sebaliknya perkembanganpariwisata malah menjadi negatif pabila melunturkan nilai-nilai budaya yang sudah ada karena masyarakatnya lebih tertarik untuk mengadopsi nilai-nilai budaya asing tanpa memahami esensinya.

Upaya untuk mencegah hal-hal negatif tentu saja dengan perencanaan yang matang yang mencakup aspek sosial merupakan cara yang efektif. Dua hal yang perlu dilakukan oleh pihak pemerintah dan perencana bisa melali dinas pariwisata. Pertama adalah melakukan penelitian tentang dampak sosial yang mungkin ditimbulkan. Kedua adalah sedapat mungkin mengikutseratakan masyarakat setempat yang memahami permaslahan dalam perencanaan dan pembangunan. Pada penduduk setempat harus dibangkitkan perasaan bahwa mereka mempunyai kepentingan terhadap keberhasilan daerah pariwisata yang bersangkutan dalam hal ini pemberdayaan potensi pariwisata di Indramayu.

\section{Jenis-jenis Pariwisata di Kabupaten Indramayu}

Sebelum membahas jenis pariwisata yang ada di Kabupaten Indramayu terlebih dahulu akan penulis ungkapkan jenis-jenis pariwisata. Apabila digeneralisir lebih luas pariwisata dilihat dari sudut motivasi para wisatawan bisa dikelompokkan ke dalam sebelas jenis, yaitu: wisata untuk menikmati perjalanan, wisata untuk rekreasi, wisata olah raga, wisata untuk urusan dagang, wisata budaya, wisata bahari, wisata cagar alam, wisata konvensi, wisata pertanian, wisata buru, dan wisata ziarah.

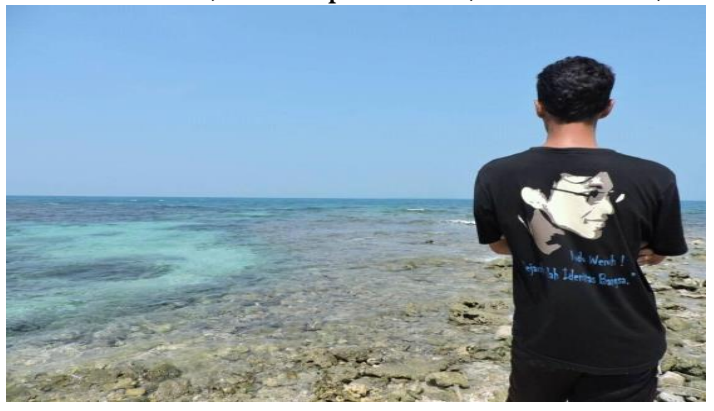

\section{Gambar 1 Pantai Tirtamaya Indramayu}

Sumber: Koleksi Pribadi, 2019 
Wisata untuk menikmati perjalanan (pleasure tourism) dilakukan oleh wisatawan yang berniat untuk erlibur, mencari udara segar, memenuhi keingintahuan, mengendorkan urat saraf, melihat sesuatu yang baru, menikmati keindahan alam, dan sebagainya. Pariwisata untuk rekreasi (recreation tourism) dilakukan oleh orang yang mau beristirahat, memulihkan kembali kesegaran jasmani dan rohani, menyegarkan keletihan dan kelelahan. Wisata olah raga meliputi peristiwa olah raga besar dan olah raga bagi mereka yang ingin berlatih atau mempraktikkannya sendiri. Wisata budaya adalah wisata yang dilakukan seseorang atas dasar motivasi untuk memperluas pandangan hidup, mempelajari keadaan masyarakat yang dikunjungi, mengetahui adat-istiadat, cara hidup, sejarah, budaya, dan seni mereka. Wisata bahari dilakukan berkaitan dengan kegiatan olah raga di air, seperti di danau, pantai, teluk, atau laut. Termasuk dalam wisata bahari adalah kegiatan berupa memancing, berlayar, menyelam, berselancar, mendayung, melihat taman laut, serta berbagai rekreasi perairan.

Wisata cagar alam (Taman Konservasi) mengkhususkan usaha-usaha wisata ke tempat atau daerah agarc alam, taman lindung, hutan daerah pegunungan, dan sebagainya yang kelestariannya dilindungi oleh undang-undang. Wisata cagar alam ini banyak dilakukan oleh para penggemar dan pecinta alam dalam kaitannya dengan kegemaran memotret binatang atau marga satwa serta pepohonan kembang beraneka warna yang memang mendapat perlindungan dari pemerintah dan masyarakat. Wisata ini banyak dikaitkan dengan kegemaran akan keindahan alam, kesegaran hawa udara di pegunungan, keajaiban hidup binatang dan marga satwa yang langka serta tumbuh-tumbuhan yang jarang terdapat di tempat-tempat lain.

Wisata konvensi dilakukan berkait dengan aktivitas seminar, konferensi, musyawarah kerja, dan sebagainya. Berbagai negara pada dewasa ini membangun wisata konvensi dengan menyediakan fasilitas bangunan dengan ruangan-ruangan tempat bersidang bagi para peserta suatu konfrensi, musyawarah, konvensi atau pertemuan lainnya baik yang bersifat nasional maupun internasional.

Wisata Pertanian (Agrowisata) berkait dengan pengorganisasian perjalanan yang dilakukan ke proyek-proyek pertanian, perkebunan, ladang pembibitan, dan sebagainya di mana rombongan wisatawan dapat mengadakan kunjungan dan peninjauan untuk tujuan studi maupun melihat-lihat keliling sambil menikmati segarnya tanaman beraneka warna dan suburnya pembibitan berbagai jenis sayur-mayur dan palawija di sekitar perkebunan yang dikunjungi. Wisata Buru banyak dilakukan di negeri-negeri yang memang memiliki daerah atau hutan tempat berburu yang dibenarkan oleh pemerintah dan digalakkan oleh berbagai agen atau biro perjalanan. Wisata buru ini diatur dalam bentuk safari buru ke daerah atau hutan yang telah ditetapkan oleh pemerintah negara yang bersangkutan.

Wisata Ziarah dikaitkan dengan agama, sejarah, adat istiadat dan kepercayaan umat atau kelompok dalam masyarakat. Wisata ziarah banyak dilakukan oleh perorangan atau rombongan ke tempat-tempat suci, ke makam- makam orang besar atau pemimpin yang diagungkan, ke bukit atau gunung yang dianggap keramat, tempat pemakaman tokoh atau pemimpin sebagai manusia ajaib penuh legenda. Wisata ziarah ini banyak dihubungkan dengan niat atau hasrat sang wisatawan untuk memperoleh restu, kekuatan batin, keteguhan iman dan tidak jarang pula untuk tujuan memperoleh berkah dan kekayaan melimpah. Di Indonesia banyak tempat-tempat suci atau keramat yang dikunjungi oleh umat-umat beragama tertentu, misalnya seperti Candi Borobudur, Prambanan, Pura Basakih di Bali, Sendangsono di Jawa Tengah, makam Wali Songo, Gunung Kawi, makam Bung Karno di Blitar, dan sebagainya.

Sesungguhnya daftar jenis-jenis wisata lain dapat saja ditambahkan di sini, tergantung kapada kondisi dan situasi perkembangan dunia kepariwisataan di suatu daerah atau negeri yang memang mendambakan industri pariwisatanya dapat maju berkembang. Pada hakikatnya semua ini tergantung kepada selera atau daya kreativitas para ahli profesional yang berkecimpung dalam bisnis industri pariwisata ini. Makin kreatif dan banyak gagasan-gagasan yang dimiliki oleh mereka yang mendedikasikan hidup bagi perkembangan dunia kepariwisataan di dunia ini, makin bertambah pula 
bentuk dan jenis wisata yang dapat diciptakan bagi kemajuan industri ini, karena industri pariwisata pada hakikatnya mempunyai prospek dan kemungkinan sangat luas, seluas cakrawala pemikiran manusia yang melahirkan gagasan-gagasan baru dari waktu ke waktu.

Apabila jenis-jenis pariwisata seperti tersebut di atas dihubungkan dengan situasi Kabupaten Indramayu maka dapat dikatakan bahwa kabupaten ini memiliki banyak jenis pariwisata. Kabupaten Indramayu sangat potensial dengan objek-objek wisata. Kondisi alam Kabupaten Indramayu memiliki daya untuk dijadikan objek wisata. Tidak kurang dari 26 objek alam yang bisa dijadikan tujuan wisata. Ke31 objek itu adalah:

1. Pantai Tirtamaya

2. Pantai Glayem

3. Pantai Karangsong (mangroove)

4. Pantai Dadap

5. Pantai Tebing Patrol

6. Pantai Cibugel

7. Pantai Eretan Wetan

8. Pantai Lemah Abang

9. Pantai Balongan Indah

10. Pantai Solikin

11. Pantai Limbangan

12. Taman Cimanuk

13. Water Boom Tirta Djaya

14. Waduk Cipancuh

15. Rangdu Gede

16. Hutan Mangrove Pantai Lestari Karangsong

17. Agung Fantasi Waterpark

18. Kolam Pemancingan Wanguk

19. Tugu Bor Kertanegara

20. Monumen Bumi Patra

21. Alun-Alun Indramayu

22. Masjid Agung Indramayu

23. Pulau Biawak Indramayu

24. Science Center Mutiara Bangsa

25. Situs Buyut Banjar

26. Jembatan Terusan Indramayu

27. Tugu Perjuangan Indramayu

28. Situ Bolang Indramayu

29. Taman Rusa Bumi Patra

30. Tiga Bintang Firdaus Waterpark

31. Waterboom Bojongsari

Berkait dengan objek ini sesungguhnya berbagai jenis wisata bisa dilakukan. Hal tersebut sangat bergantung pada niat dan motivasi wisatawannya. Terhadap ke-26 objek alam ini bias dilakukan wisata jenis wisata untuk menikmati perjalanan, wisata untuk rekreasi, wisata olah raga, wisata budaya, wisata cagar alam, wisata pertanian, dan wisata buru. Di samping itu Kabupaten Indramayu pun memiliki objekobjek budaya yang bisa dijadikan objek wisata. Tidak kurang dari 35 objek budaya, yaitu:

1. Situs Pemakaman Raden Arya Wiralodra 
2. Situs Koloni Kera Banjar

3. Makam Buyut Tambi

4. Lingkung Seni Topeng Dermayon

5. Rumah Budaya Mama Sugra

6. Sandiwara wayang wong Dermayu

7. Wayang Kulit Langen Budaya

8. Makam Pangeran Selawe

9. Upacara Ngarot Lelea

10. Sintren Dermayu

11. Batik Paoman Dermayu

12. Rudat Akrobat

13. Berokan Jaran Lumping

14. Wihara Dharma Rahayu

15. Pedati Kuno

16. Masjid Bondan

17. Makam Nyimas Kawunganten

18. Makam Bupati Djrali

19. Makam Kyai Syakir Wotgali

20. Situs Sumur Santri

21. Bedug Kramat Jatisawit di Mayahan

22. Situs Makam Habib Keling

23. Situs Makam Kramat Jatilawang Pawidean

24. Situs Kramat Dampu Awang

25. Pesantren Al-Zaytun

26. Islamic Center Indramayu

27. Situs Kramat Butut Gentong

28. Komunitas Dayak Bumi Segandu

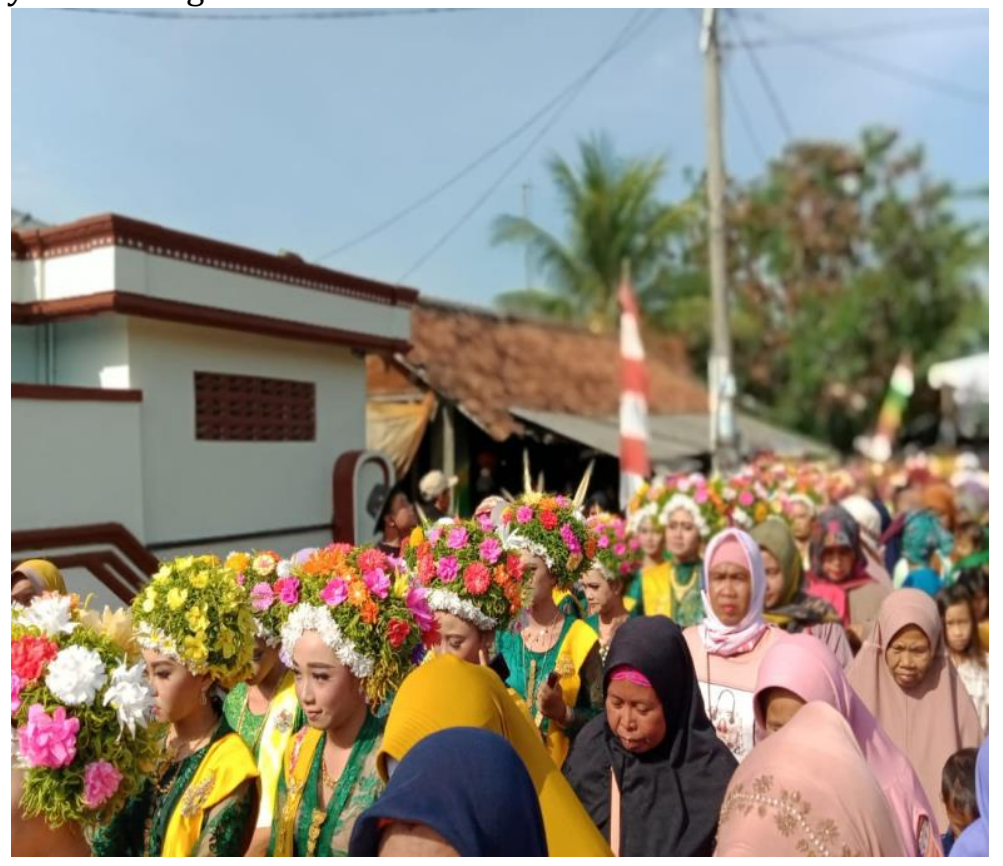

\section{Gambar 2 Arak-arakan dalam upacara Ngarot di Lelea Sumber: Dokumen Pribadi}


Terhadap ke-35 objek budaya ini pun wisatawan dapat melakukan aktivitas wisata sesuai dengan niat dan motivasi masing-masing. Tujuan wisata ke objek ini bisa sebagai wisata untuk menikmati perjalanan, wisata untuk rekreasi, wisata olah raga, wisata budaya, dan wisata ziarah. Bahkan untuk objekobjek tertentu bisa dilakukan wisata ziarah dan wisata sejarah, yaitu untuk objek-objek:

Makam Raden Arya Wiralodra, Makam Pangeran Selawe, Makam Buyut Tambi, Makam Bupati Djrali, Makam Kyai Syakir Wotgali, Situs Sumur Santri, Bedug Kramat Jatisawit di Mayahan, Situs Makam Habib Keling, Situs Makam Kramat Jatilawang, Situs Kramat Dampu Awang.

Sedangkan Pusat Agrobisnis di Indramayu diantaranya:

1. Sentra Krupuk Udang dan Krupuk Kulit di Desa Kenanga Dukuh. Memproduksi dan mendistribusikan langsung sebagai bagian kerja kerja home industri.

2. Sentra Perkebunan Mangga dan olahan Mangga di Kecamatan Jatibarang, Kecamatan Sliyeg, Kecamatan Trisi, Kecamatan Cikedung apabila musim panen tiba biasanya di bulan AgustusDesember. Banyak sekali jenis Mangga Indramayu diantaranya Mangga Gedong Gincu, Mangga Cengkir, Mangga Harum Manis, Mangga Simanalagi, Mangga Oceng, Mangga Golek, Mangga Budiraja dan sebagainya.

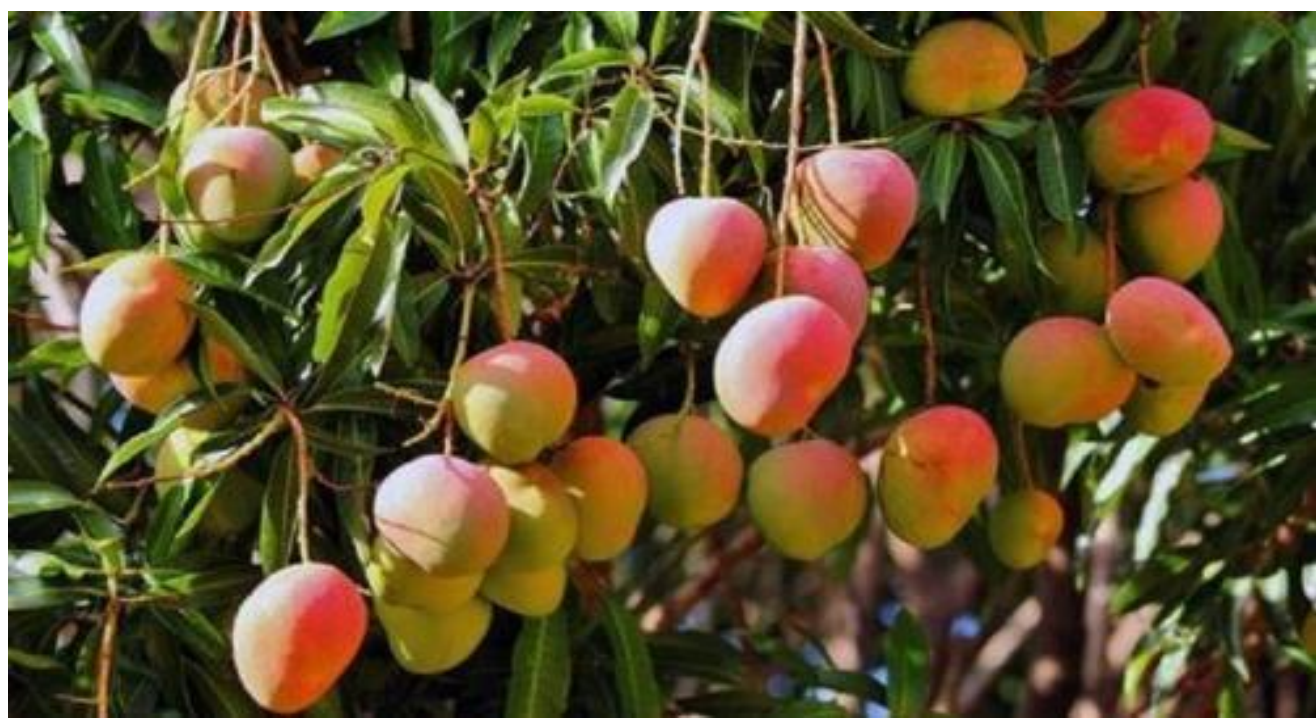

\section{Gambar 3 Foto Mangga Gedong Gincu, Sumber: Okezone, 2020}

Tidak kalah juga kuriner jajanan khas Indramayu (1) pemetaan wisata kulinerKabupaten Indramayu dibagi menjadi 9 kawasan, yaitu kawasan Karangampel, kawasan Juntinyuat, kawasan Balongan, kawasan Indramayu, kawasan Sindang,dan kawasan Jatibarang, Kawasan Kandanghaur, Kawasan Patrol, Kawasan Haurgeulis (2) makanan Khas Kabupaten Indramayu kategori laukpauk adalah Pindang Gombyang, Pedesan Entog, Sate Biyawak, dan Krecek Urang; kategori makanan sepinggan khas Kabupaten Indramayu adalah Bubur Rumbah cecek (Burbacek), Rumbah, dan Ramusan Remucu; kategori makanan insidental khas Kabupaten Indramayu adalah Rumbah Edan, Cimplo, Bubur Lemu, Lepet, dan Koci; kudapan khas Kabupaten Indramayu adalah Sempora, Blengep, Geblog, Belendung Jagung, Krawu Boled, Gonjing, Limpung, Botok Sarikaya, Ongolongol, Buras, Cikak, Jalabiya, dan Belencong; oleh-oleh khas Kabupaten Indramayu adalah Mangga segar varietas Cengkir, Keripik Melinjo, Keripik Tike, Dodol Enom, Lara Gudeg, Dodol Mangga, Sirup Mangga, Keripik Mangga, dan Terasi Junti; sambal khas Kabupaten Indramayu adalah Sambal Gecok, dan (3) karakteristik wisatawan kuliner domestik di Kabupaten Indramayu berjenis kelamin pria sebanyak 55,34\%, kisaran usia antara 21-25 tahun 31,07\%, berpendidikan terakhir SMA/Sedrajat 40,78\%, bekerja sebagai karyawan swasta $24,30 \%$, dengan 
penghasilan kurang dari Rp 500.000,00 sebesar 33,98\%, berasal dari Kabupaten Indramayu 70,87\%, datang ke sentra kuliner bersama teman/kelompok/rombongan 54,37\%, intensitas kunjungan kurang dari 3 kali dalam sebulan 64,08\%. Alasan mengunjungi sentra kuliner dengan pertimbangan kualitas makanan 33,98\%. Alasan khusus wisatawan adalah untuk mendapatkan pengalaman mencicipi makanan yang baru dan baik sebesar 60,19\% (Wiwin, 2014:ii).

Secara teoretis, untuk menjadikan suatu kawasan sebagai objek wisata yang berhasil haruslah diperhatikan beberapa faktor berikut ini:

1. Faktor kelangkaan (scarcity), yakni objek wisata yang tidak dapat dijumpai di tempat lain, baik yang bersifat alami maupun yang bersifat ciptaan.

2. Faktor kealamiahan (naturalism), yakni sifat objek wisata yang belum tersentuh oleh perubahan akibat perilaku manusia. Misalnya, objek wisata berupa atraksi wisata yang berwujud warisan budaya atau atraksi alam yang belum mengalami banyak perubahan oleh perilaku manusia.

3. Faktor Keunikan (uniqueness) yakni sifat objek wisata yang memiliki keunggulan komparatif dibanding dengan objek lain yang ada id sekitarnya.

4. Faktor pemberdayaan masyarakat (community empowerment). Faktor ini berupa sikap masyarakat lokal di sekitar objek wisata yang benar-benar dapat diberdayakan dengan keberadaan suatu objek wisata di daerahnya, sehingga masyarakat merasa memiliki. Sikap seperti ini akan menimbulkan sifat ramah tamah terhadap wisatawan yang berkunjung.

5. Faktor optimalisasi lahan (area optimalization), yakni lahan yang dipakai sebagai kawasan wisata alam digunakan berdasarkan pertimbangan optimalisasi sesuai dengan mekanisme pasar, tanpa melupakan pertimbangan konservasi, preservasi, dan proteksi.

6. Faktor pemerataan, yakni pengaturan kemanfaatan sehingga keuntungan terdistribusikan secara proporsional bagi masyarakat. Dengan demikian, akan tercipta ketertiban masyarakat tuan rumah sehingga menjadi utuh dan padu dengan pengelola kawasan wisata (Utama, 2006).

Objek-objek wisata yang ada di kabupaten ini tampaknya dapat memenuhi keenam faktor tersebut di atas. Yang menjadi persoalan penting untuk diperhatikan oleh Pemerintah Daerah Kabupaten Indramayu supaya daerahya menarik banyak wisatawan adalah berkait dengan kualitas lokasi, fasilitas, citra/image, harga/tarif, dan pelayanan. Dalam tataran praksis, tentu saja, di sini harus disebut faktor promosi.

\section{SIMPULAN}

Kabupaten Indramayu memiliki alam yang sangat potensial untuk dijadikan objek wisata. Tidak banyak daerah yang memiliki keunggulan seperti ini. Oleh karena itu, sangat bergantung pada keseriusan Pemerintah Daerah Kabupaten sendiri apakan potensi ini akan diaktualkan secara maksimal atau tidak. Yang pasti adalah kegiatan kepariwisataan sangat menjanjikan keuntungan dalam berbagai segi kehidupan: ekonomi, sosial, budaya, dan sebagainya.

Kegiatan kepariwisataan dapat mendinamisasi dan mengakselerasi perkembangan berbagai hal. Positif dan negatifnya dampak dari aktivitas kepariwisataan sangat terkait dengan banyak faktor, di antaranya perencanaan dan pengelolaan yang professional. Di Samping itu peran aktif masyarakat Indrmayu dalam menjaga kondusifitas keamanan dan ketentraman di lingkungan obyek wisata sangat dibutuhkan, isu miring tentang kurang ramahnya masyarakt Indramayu terhadap pendatang bisa terkikis dengan sendirinya.

\section{DAFTAR REFERENSI}

Al Akbar, Wiwin. 2014. Studi Potensi Wisata Kuliner di Kabupaten Indramayu Provinsi Jawa Barat. Skripsi. Fakultas Teknik Universitas Negeri Yogyakarta (UNY): Yogyakarta. 
Iryana, Wahyu. 2019. "Stategi Mengatasi Kemiskinan Nelayan Eretan Weran, Indramayu. Jurnal Historia Madania: Jurnal Ilmu Sejarah, 3 (2). ISSN: 2088-2289.

Utama, I Gusti Bagus Rai. 2006. "Konsep Pariwisata (Kajian Sosiologi dan Ekonomi)”, dalam http://raiutama.blog.friendster.com/2006/09/konsep-pariwisata/ (diakses 6 Februari 2010).

Darmoprajitno, H, Soewarno.2001. Ekologi Pariwisata, Tata Laksana Pengelolaan Objek dan Daya Tarik Wisata. Bandung: Angkasa.

Pitana, I Gede. 2005. Sosiologi Pariwisata, Kajian sosiologis terhadap struktur, Sistem, dan Dampakdampak Pariwisata. Yogyakarta: Andi Offset.

Soekadijo, R.G. 2000. Anatomi Pariwisata, Memahami Pariwisata sebagai Sistem Lingkage. Jakarta: Gramedia Pustaka Utama.

Spillane, James.1985. Ekonomi Pariwisata, Sejarah dan Prospeknya.Yogyakarta: Kanisius.

Yoeti, Oka.1997. Pemasaran Pariwisata Terpadu. Jakarta: Angkasa. 
Halaman ini sengaja dikosongkan 